JURNAL PENDIDIKAN USIA DINI

DOI: https://doi.org/10.21009/JPUD.112
DOI: https://doi.org/10.21009/JPUD.112.05

\title{
ENVIRONMENTAL SENSITIVITY DAN HUBUNGANNYA DENGAN PERILAKU PELESTARIAN KEARIFAN LOKAL PADA ANAK USIA DINI MASYARAKAT SUKU SASAK
}

\author{
NADIROH'-RIZKI ANANDA ${ }^{2}$ \\ DosendanMahasiswa Universitas Negeri Jakarta \\ Jl. Rawamangun Muka, Jakarta Timur 13220 \\ Email: nadiroh@unj.ac.id, \\ rizkianandari22@gmail.com
}

\begin{abstract}
Previous research said that environmental sensitivity in students and adult give effect to forming citizenship behavior. The purpose of this research is to know the relationship between environmental education and local wisdom that is taught to the children in shaping the environmental sensitivity of sasak tribe of Desa Sasak Ende Lombok West Nusa Tenggara. The research was conducted quantitatively by using questionnaires to 10 respondents representing 30 heads of households. Based on the results obtained pearson $r$ value of 0.868 with Sig. (2-tailed) of 0.001 or less than 0.05 It shows that there is a positive relationship between environmental sensitivity and the local wisdom behavior of early childhood
\end{abstract}

Keywords: environmetantal sensitivity, local wisdom, sasak tribe, early childhood.

\begin{abstract}
Abstrak: Penelitian sebelumnya menyatakan bahwa environmental sensitivity pada peserta didik dan orang dewasa berperan dalam pembentukan perilaku bijak terhadap lingkungan. Penelitian ini bertujuan untuk mengetahui apakah terdapat hubungan antaraenvironmental sensitivity dengan perilaku pelestarian kearifan lokal pada anak usia dini yang diajarkan di keluargamasyarakat suku sasak Desa Sasak Ende Lombok Nusa Tenggara Barat. Penelitian dilakukan secara kuantitatif dengan menggunakan kuesioner terhadap 10 responden yang mewakili 30 keluarga. Berdasarkan hasil diperoleh nilai $r$ Pearson sebesar 0,868 dengan Sig. (2-tailed) sebesar 0,001 atau kurang dari 0,05 sehingga ada hubungan positif antaraenvironmental sensitivity dengan perilaku pelestarian kearifan lokal pada anak usia dini.
\end{abstract}

Keywords: environmetantal sensitivity, kearifan lokal, suku sasak, anak usia dini

\section{PENDAHULUAN}

Pada sebagian masyarakat di daerah tertentu, budaya dan kebiasaan masih tetap dijaga dan dipertahankan, meskipun terdapat pengaruh arus perubahan. Kebiasaan yang mengandung nilai-nilai dan aturan yang berkembang di masyarakat secara turun-temurun itu disebut kearifan lokal (Kementrian Kebudayan dan Pariwisata, 2011). Kearifan lokal dapat membawa kepada keberlangsungan 
JURNAL PENDIDIKAN USIA DINI

Volume 11 Edisi 2, November 2017

kehidupan yang sustainable atau

berkembang di masyarakat sebagai berkelanjutandikarenakan mengandung nilai-nilai pelestarian dan pengelolaan alam dan lingkungan secara bijaksana (Andi, M, 2010).

Perilaku yaitu segala sesuatu berupa tidakan yang kita lakukan, baik verbal maupun non verbal serta dapat langsung dilihat atau diamati (Santrock, 2009). Pelestarian kearifan lokal juga dapat dikatakan sebagai perilaku bijak terhadap lingkungan karena memperlakukan alam secara bijak sesuai dengan aturan dan norma yang berlaku di masyarakat tersebut. Kearifanlokal(local wisdom) terdiridaridua kata yaitukearifan(wisdom) danlokal(local).Local berartisetempats edangkan wisdom(kearifan)yang bermaknakebijaksanaan.

Secaraumummaka local wisdo(kearifansetempat) dapatdipahamisebagaigagasangagasansetempatyang bersifatbijaksana, penuhkearifan, bernilaibaik, yang tertanamdandiikutiolehanggotamasyar akatnya(Susilo, 2009). Kearifan lokal 252 
Environmental Sensitivity dan Hubungannya... Nadirah\&Rizki Ananda

menenun dan membuat kerajinan tangan.

Upaya yang dilakukan dalam menjaga nilai kearifan lokal dilakukanorang tua dari tiap-tiap keluarga Suku adalah memurunkannya kepada anak-anaknya sejak anak berusia dini secara lisan dengan berpesan kepada anak-anak mereka. Sebagai contoh, salah satu pesan dari orang tua mereka adalah jika tetap ingin tinggal didaerah setempat, maka anak tersebut harus membuat rumah seperti model dan bahan bangunan yang sudah ada serta taat akan aturan desa dalam menjaga sumber daya alam sekitar (Andi, M, 2010).

Menurut Setiowati (2012), kearifan lokal tentunya dapat ditumbuhkan dalam diri anak sejak usia dini melalui pendidikan nilai yang tercermin dan terintegrasi pada bidang pengembangan moral-agama, sosialemosi.

Undang-undang RI Nomor 20 tahun 2003 tentang Sistem Pendidikan Nasional pada Pasal 1 ayat 14 menyatakan bahwa pendidikan anak usia dini bagi anak yang berusia 0-6 tahun. Sedangkan menurut National Association for The Education of Young Chldren (NAEYC) anak usia dini adalah anak-anak dengan usia 0-8 tahun. Pendidikan anak usia dini secara formalmerupakan pendidikan sebagai wahana untuk menyiapkan anak dari segi sikap, pengetahuan, dan keterampilan guna memasuki sekolah dasar (Aisyah, 2011). Menurut Setyowati (2012), kearifan lokal pada anak usia dini adalah nilai-nilai sikap yang mendasari perilaku anak, yang dilandasi oleh nilai-nilai luhur budaya kita. Nilai-nilai luhur budaya kita dapat dilestarikan dengan jalan mewariskan dari generasi tua ke generasi muda melalui pendidikan, baik itu pendidikan formal, informal, maupun nonformal. Dengan demikian dapat dikatakan bahwa kebudayaan dan pendidikan mempunyai hubungan timbal balik. Sebaliknya bentuk, ciriciri dan pelaksanaan pendidikan itu ditentukan oleh kebudayaan masyarakat dimana proses pendidikan itu berlangsung.

Pendidikan kearifan lokal pada anak usia dini dapat dilakukan dengan 
JURNAL PENDIDIKAN USIA DINI

Volume 11 Edisi 2, November 2017

dengan penanaman nilai dan pendidikan karakter bagi anak dengan cara lisan atau nasehati seperti pembacaan dongeng. Selain itu juga dapat dilakukan dengan cara lain seperti bergotong royong (Setiowati, 2012).

Perilaku pelestarian kearifan lokal dapat dikatakan sebagai perilaku bijak terhadap lingkungan. Hungerford,H.E., Volk,T.L menyatakan bahwa, terdapat tiga kategori variabel utama yang berkontribusi terhadap perilaku bijak terhadap lingkungan. Ketiga kategori tersebut yaitu (1) entry-level variables yang merupakan prediktor perilaku yang bertanggungjawab terhadap lingkungan berupa environmental sensitivity; (2)ownership variables, empowerment variablesberupa knowledge atau pengetahuan; (3) Empowerment berupalocus of controluntuk mencapai perilaku bijak terhadap lingkungan. Environmental sensitivity merupakan satu-satunya Major variable yang terdapat di dalam entry level variable sehingga peran dari environmental sensitivity sangat 254 
Environmental Sensitivity dan Hubungannya... Nadirah\&Rizki Ananda

Sebagai salah satu syarat dalam dari pengaruh lingkungan. Setiap mewujudkan environmental spesies mengalami hal tersebut, literacyEnvironmental sensitivity termasuk manusia. Pola yang sangat penting untuk dipahami dan nampaknya muncul secara konsisten dimiliki oleh peserta $\operatorname{didik}($ Sivek, dapat berupa keberanian, agresif, 2012).Environmental sensitivity mengacu pada perbedaan respon yang baru ditemui (Chawla, 1998). perilaku dari tiap-tiap individu akibat

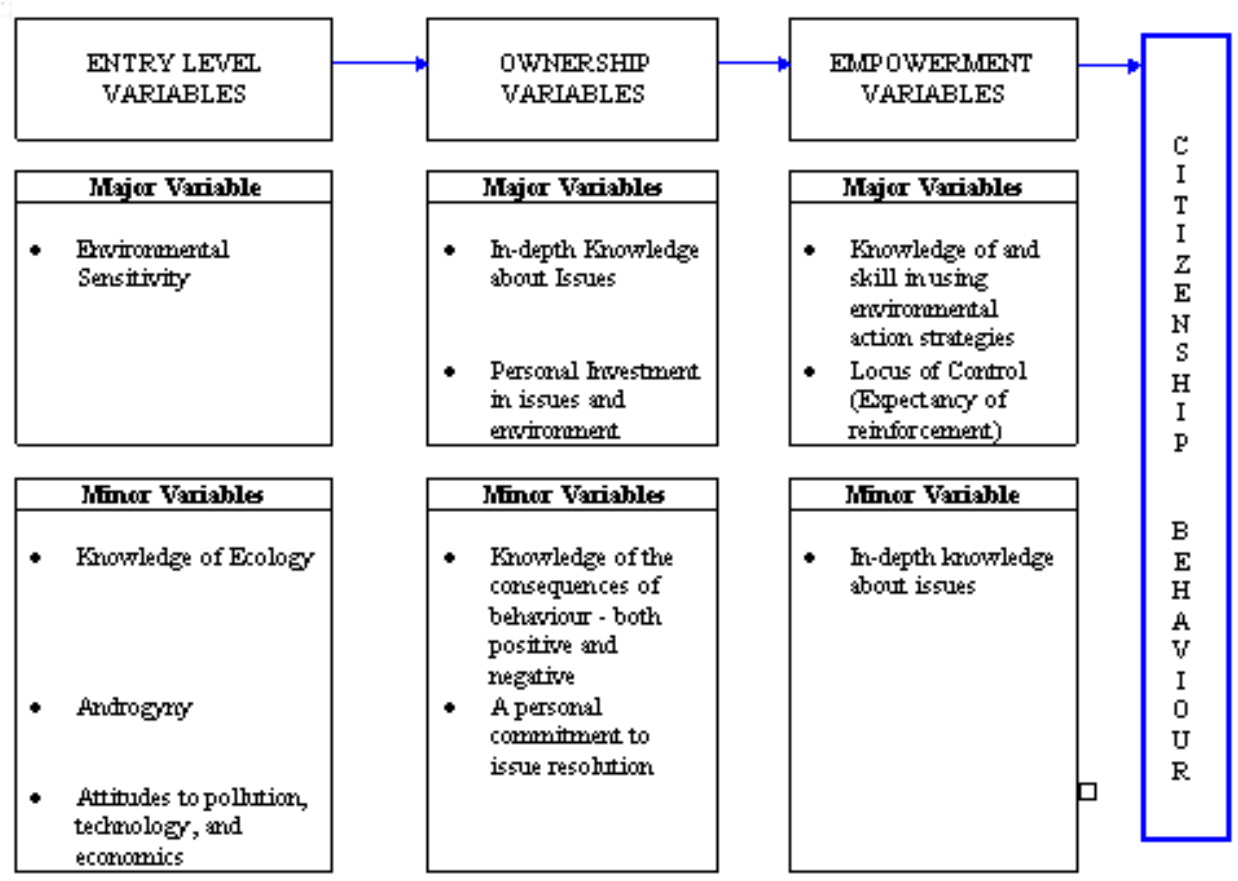

\section{Gambar 1.}

Flowchart Perilaku Bijak terhadap Lingkungan(Hungerford \& Volk,1990)

\section{Environmental sensitivity lalu) dan reaktivitas (menanggapi}

mengacu pada aspek persepsi dan pengalaman saat ini) (Pluess, M, mencerminkan dua hal yaitu 2015).

menggambarkan proses perkembangan

Berdasarkan penelitian (berubah seiring waktu sebagai sebelumnya di lembaga pendidikan respons terhadap pengalaman masa dikatakan bahwa penting bagi pendidik 
JURNAL PENDIDIKAN USIA DINI

Volume 11 Edisi 2, November 2017

untuk lebih memahami environmental sensitivity(Sivek, 2012) dan untuk memfasilitasi perkembangannya pada peserta didik (Metzger, Tina and Douglas Mcwen, 1999). Pengembangan instrumen Environmental sensitivity yang berpengaruh terhadap wawasan lingkungan guru PAUD di Jakarta juga pernah dilakukan (Sunaryo dan Yossa Istiadi, 2017). Sebuah studi menyatakan bahwa environmental sensitivitypada orang dewasa di sembilan negara juga mendukung pentingnya pengalaman agar dapat menjadi contoh atau role mode bagi anak-anak atau peserta didik agar dapat membentuk perilaku dalam menjaga lingkungan (Palmer et al., 1998).

Berdasarkan penelitian sebelumnya yang telah dilakukan di tingkat sekolah pada peserta didik maupun guru serta orang dewasa di masyarakat umum mengenai environmental sensitivity, maka dipandang perlu untuk dilakukan penelitian untuk mengetahui hubungan environmental sensitivity dengan 256 perilaku pelestarian kearifan lokal pada tingkat keluarga di masyarakat daerah yang dalam hal ini adalah masyarakat Suku Sasak Desa Sasak Ende Lombok Tengah Nusa Tenggara Barat mengingat keluarga adalah elemen dasar dan penting di sebuah tatanan masyarakat yang dapat membentuk karakter anak dan anggota keluarga dalam menjaga lingkungan.

\section{METODE PENELITIAN}

Penelitian ini menggunakan metode survei dengan variabel dalam penelitian ini adalahenvironmental sensitivity dan perilaku pelestarian kearifan lokal. Lokasi penelitian berada di Desa Wisata Sasak EndeKabupaten Lombok tengah Nusa Tenggara Barat. Waktu pelaksanaan penelitian yaitu Bulan April 2017.

Populasi dalam penelitian ini adalah masyarakat Suku Sasak di Desa Sasak Ende Lombok Tengah Nusa tenggara Barat.Pengambilan sampel dilakukan dengan cara random sampling. Sampel dalam penelitian ini adalah 10 orang berupa anak anak 
Environmental Sensitivity dan Hubungannya... Nadirah\&Rizki Ananda

usia dini diambil mewakili jumlah populasi dengan jumlah 30 keluarga.

Data dalam penelitian ini menggunakan kuesioner. Dikarenakan sebagian besar responden sedang melakukan aktivitas bermain,pertanyaan diberikan dengan melakukan pendekatan, komunikasi langsung, dan wawancara singkat kepada responden sesuai dengan daftar pertanyaan yang telah disusun sesuai kisi-kisi. Bagi masyarakat yang kurang mengerti Bahasa Indonesia, maka peneliti meminta bantuan dari pemuka adat setempat.Instrumen PerilakuPelestarian Kearifan Lokal pada Tabel 1 dan kisi-kisi environmental sensitivity pada Tabel 2 yang mengacu pada instrumen environmental sensitivity quitionaire (ESQ) yang telah dikembangkan oleh Metzger, Tina dan Mcewen Douglas (1999).

Tabel 1

Instrumen Perilaku Pelestarian Kearifan Lokal

\begin{tabular}{clcc}
\hline No & Indikator & $\begin{array}{c}\text { No. Butir } \\
\text { Pertanyaan }\end{array}$ & Jumlah \\
\hline 1 & Melaksanakan aturan tempat tinggal & 1,2 & 2 \\
\hline 2 & Mengelola sumber daya tempat tinggal secara bijak & 3,4 & 2 \\
\hline 3 & Menggunakan produk ramah lingkungan (go green) & 5,6 & 2 \\
\hline 4 & Mencintai lingkungan tempat tinggal & 7,8 & 2 \\
\hline 5 & Mencegah pencemaran lingkungan & 9,10 & 2 \\
\hline \multicolumn{4}{c}{ Total } \\
\hline
\end{tabular}

Tabel 2

Instrumen Environmental Sensitivity

\begin{tabular}{|c|c|c|c|c|}
\hline No & & Indikator & $\begin{array}{l}\text { No. Butir } \\
\text { Pertanyaan }\end{array}$ & Jumlah \\
\hline \multirow[t]{2}{*}{1} & $\begin{array}{l}\text { Menggambarkan } \\
\text { proses } \\
\text { perkembangan } \\
\text { (berubah seiring }\end{array}$ & $\begin{array}{l}\text { Mampu beradaptasi secara } \\
\text { fenotipe } \\
\text { dari waktu ke waktu dengan } \\
\text { kondisi lingkungan tertentu. }\end{array}$ & 1,2 & 2 \\
\hline & $\begin{array}{l}\text { waktu sebagai } \\
\text { respons terhadap } \\
\text { pengalaman masa } \\
\text { lalu) }\end{array}$ & $\begin{array}{l}\text { Bertahan dalam kondisi yang } \\
\text { dinamis dalam jangka waktu } \\
\text { yang cukup lama }\end{array}$ & $3,4,5$ & 3 \\
\hline
\end{tabular}


JURNAL PENDIDIKAN USIA DINI

Volume 11 Edisi 2, November 2017

\begin{tabular}{|c|c|c|c|c|c|}
\hline \multirow{2}{*}{\multicolumn{2}{|c|}{$\begin{array}{ll}3 & \text { Reaktivitas } \\
& \text { (menanggapi } \\
\text { pengalaman saat } \\
\text { ini) }\end{array}$}} & \multicolumn{2}{|c|}{$\begin{array}{l}\text { Merasakan gejala/peristiwa di } \\
\text { sekitar yang berbeda dari kondisi } \\
\text { biasanya. }\end{array}$} & 6,7 & 2 \\
\hline & & \multicolumn{2}{|c|}{$\begin{array}{l}\text { Merespon secara aktif terhadap } \\
\text { gejala/peristiwa yang tidak biasa } \\
\text { yang terjadi di lingkungan }\end{array}$} & $8,9,10$ & 3 \\
\hline & & & Tota & & 10 \\
\hline \multicolumn{3}{|c|}{ HASIL DAN PEMBAHASAN } & \multicolumn{3}{|c|}{ sehingga pola hubungan antara kedua } \\
\hline \multirow{2}{*}{\multicolumn{3}{|c|}{$\begin{array}{l}\text { Berdasarkan hasil perhitungan data } \\
\text { yang dipeoleh, maka untuk menyusun }\end{array}$}} & \multirow{3}{*}{\multicolumn{3}{|c|}{$\begin{array}{l}\text { variabel ini dinyatakan oleh persamaan } \\
\text { regresi } \hat{\mathrm{Y}}=32,85+0,37 \mathrm{X} . . \text { Bentuk } \\
\text { hubungan positif antara environmental }\end{array}$}} \\
\hline & & & & & \\
\hline \multicolumn{3}{|c|}{ model persamaan regresi antara } & & & \\
\hline \multicolumn{3}{|c|}{ environmentalsensitivity dan } & \multicolumn{3}{|c|}{ sensitivity dengan perilaku pelestarian } \\
\hline \multicolumn{3}{|c|}{ pelestarian kearifan lokal diperoleh } & \multicolumn{3}{|c|}{ kearifan lokal ditunjukkan dengan nilai } \\
\hline \multicolumn{3}{|c|}{ konstanta regresi a $=32,85$ dan } & \multicolumn{3}{|c|}{ koefisien $r_{x y}=0,868($ Gambar 1$)$} \\
\hline \multicolumn{6}{|c|}{ koefisien korelasi $b=0,37 .($ Tabel 4$)$} \\
\hline
\end{tabular}

Tabel 3

Koefisien Persamaan Regresi

\begin{tabular}{|c|c|c|c|c|c|}
\hline \multirow[b]{2}{*}{ model } & \multicolumn{2}{|c|}{$\begin{array}{c}\text { Unstandardized } \\
\text { Coefficients }\end{array}$} & \multirow{2}{*}{$\begin{array}{c}\text { Standardized } \\
\text { Coefficients }\end{array}$} & \multirow[b]{2}{*}{$\mathrm{t}$} & \multirow[b]{2}{*}{ Sig. } \\
\hline & $\mathrm{B}$ & Std. Error & & & \\
\hline $1 \quad$ (Constant) & 32,851 & 3,297 & & 9,965 &, 000 \\
\hline Environmental Sensitivity &, 370 & ,075 & ,868 & 4,935 & ,001 \\
\hline
\end{tabular}

a. Dependent Variable: Pelestarian Kearifan Lokal

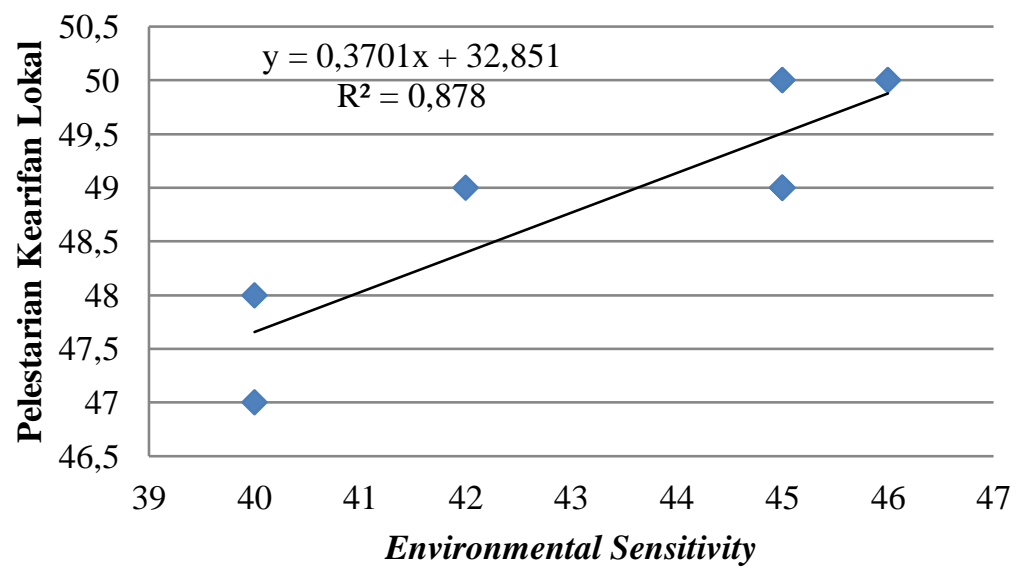


Environmental Sensitivity dan Hubungannya... Nadirah\&Rizki Ananda

\section{Gambar 1. Grafik Persamaan Regresi}

Sebelum model persamaan uji signifikansi dan linearitas regresitersebut dianalisis lebih lanjut persamaan regresi. Hasil perhitungan dan digunakan dalam menarik uji signifikansi dan linearitas disusun kesimpulan, terlebih dahulu dilakukan pada tabel ANAVA pada Tabel 4.

Tabel 4

ANAVA untuk uji signifikansi dan Linearitas Persamaan Regresi $\hat{Y}=32,85+0,37 \mathrm{X}$

\section{ANOVA $^{\mathrm{a}}$}

\begin{tabular}{|ll|r|r|r|r|r|}
\hline \multicolumn{2}{|l|}{ Model } & \multicolumn{1}{c|}{$\begin{array}{c}\text { Sum of } \\
\text { Squares }\end{array}$} & Df & Mean Square & F & Sig. \\
\hline 1 & Regression & 6,700 & 1 & 6,700 & 24,358 &, $001^{\mathrm{b}}$ \\
& Residual & 2,200 & 8 &, 275 & & \\
& Total & 8,900 & 9 & & & \\
\hline
\end{tabular}

a. Dependent Variable: Perilaku Pelestarian Kearifan Lokal

b. Predictors: (Constant), Environmental Sensitivity

Persamaan regresi $\hat{\mathrm{Y}}=32,85+$

0,37X, untuk uji signifikansi diperoleh

tingkat signifikansi pada tabel sebesar

$0,001<0,05$ maka persamaan regresi

dinyatakan sangat signifikan.

Persamaan tersebut menyatakan bahwa perilaku pelestarian kearifan lokal dapat diperediksi dari prediktor environmental sensitivity.

Selanjutnya, hipotesis yang diajukan dalam penelitian ini yaitu terdapat hubungan positif antara environmental sensitivity (X) dengan perilaku pelestarian kearifan lokal (Y).

Berdasarkan hasil perhitungan antara environmental sensitivity dengan perilaku pelestarian kearifan lokal bahwa diperoleh nilai Pearson's $r$ sebesar 0,868 dengan Sig. (2-tailed) sebesar 0,001 atau lebih kecil dari $\alpha=$ 0,05 sehingga dapat dikatakan bahwa terdapat hubungan positif antara environmental sensitivity dengan perilaku pelestarian kearifan lokal (Tabel 4). Dengan kata lain makin tinggi environmental sensitivity, maka 
JURNAL PENDIDIKAN USIA DINI

Volume 11 Edisi 2, November 2017

makin tinggi perilaku pelestarian koefisien korelasi antara variabel kearifan lokal. Adapun besarnya Xdengan Y dapat dilihat pada Tabel 5.

Tabel 5

Hubungan antara Pendidikan lingkungan dan pelestarian Kearifan Lokal denganEnvironmental Sensitivity

\begin{tabular}{llrr}
\hline & & $\begin{array}{c}\text { Environmental } \\
\text { Sensitivity }\end{array}$ & \multicolumn{2}{c}{$\begin{array}{c}\text { Perilaku Pelestarian } \\
\text { Kearifan Lokal }\end{array}$} \\
\hline $\begin{array}{l}\text { Environmental } \\
\text { Sensitivity }\end{array}$ & Pearson & 1 &, $868^{* *}$ \\
& Correlation & Sig. (2-tailed) &, 001 \\
& $\mathrm{~N}$ & 10 & 10 \\
\hline Perilaku & Pearson &, $868^{* *}$ & 1 \\
Pelestarian & Correlation &, 001 & 10 \\
Kearifan Lokal & Sig. (2-tailed) & 10 & \\
$* *$ Correlation is & $\mathrm{N}$ significant at the 0.01 level (2-tailed). &
\end{tabular}

Keterangan :

** = Korelasi sangat signifikan jika nilai sinifikansi > 0,05

Environmental Sensitivity Indikator pertama yang masyarakat Suku Sasak Desa Sasak menggambarkan enviromental Ende Lombok Tengah Nusa Tenggara sensitvity mayarakat pada instrumen Barat membawa mereka untuk tetap penelitian ini adalah mampu konsisten dalam melakukan pelestarian menggambarkan proses perkembangan kearifan lokal. Hal tersebut tercermin atau dapat berubah seiring waktu dari aturan dan aktivitas mereka sebagai respons terhadap pengalaman sehari-hari. Kondisi keluarga yang masa lalu. Hal ini terlihat bahwa harmonis dengan tetap memberikan mereka tetap mengalami perubahan edukasi kepada anak dan generasi akan kemajuan zaman, namun sebagai penerus Suku Sasak akan memberikan respon dari pertahanan diri dan budaya dampak bagi pembentukan karakter mereka tetap melaksanakan aturan adat anak-anak tersebut.

walaupun terdapat perubahan seperti 
Environmental Sensitivity dan Hubungannya... Nadirah\&Rizki Ananda

pemberlakuan pemerintah daerah setempat untuk menjadikan desa mereka menjadi desa wisata. Banyak wisatawan domestik bahkan mancanegara yang berkunjung dengan membawa pengaruh modernisasi, namun anak-anak mereka tetap diajarkan akan norma dan budaya yang harus dipegang teguh. Pada penelitian sebelumnya (Palmer et al., 1998) dikatakan bahwa environmental sensitivity padaorang dewasa akan dapat menjadikan mereka role mode bagi orang lain. Edukasi tersebut dilakukan oleh masing-masing orang tua di tiap-tiap keluarga serta terdapat pengajian dan ceramah kepada masyarakat dan anak-anak di setiap hari Jumat yang dilakukan oleh tetua adat setempat.

Indikator kedua yaitu reaktivitas atau menanggapi pengalaman saat ini. Sebagian besar masyarakat Suku Sasak Desa Sasak Ende Lombok Tengah Nusa Tenggara Barat memahami bahwa saat ini semakin banyak yang mengunjungi desa mereka khususnya dan Provinsi Nusa Tenggara Barat umumnya karena dikenal sebagai salah satu destinasi wisata di Indonesia. Reaksi mereka tercermin dari jawaban-jawaban yang ada di kuisioner dan secara umum menggambarkan bahwa mereka tidak keberatan namun tetap teguh dalam menjaga adat dan kondisi lingkungan tempat tinggal mereka. Anak- anak suku sasak pun menyambut baik kedatangan turis lokal maupun internasional.

Berkaitan dengan pendidikan kearifan lokal pada anak usia dini menurut Setiowati (2012:740), maka kearifan lokal yang tercermin pada perilaku budaya kita, perlu ditumbuhkan melalui pengenalan budaya setempat, yang menganut nilainilai kesopanan, kebersamaan, gotong royong, saling menolong sesama, tenggang rasa. Dengan demikian produk kebudayaan yang mencerminkan kearifan lokal bisa berwujud perilaku.yang sesuai dengan norma agama, dan norma sosial pada anak usia dini.

Hal tersebut sesuai dengan yang telah dilakukan oleh orang tua masyarakat Suku Sasak yang mana 
JURNAL PENDIDIKAN USIA DINI

Volume 11 Edisi 2, November 2017

terdapat beberapa upaya pelesarian

kearifan lokal yang mereka lakukan

dan ajarkan kepada anak-anak mereka.

Permukiman penduduk di daerah

selatan Lombok umumnya terletak di

dataran tinggi atau perbukitan yang

tidak ditanami atau kurang subur. Hal

tersebut dicontohkan dan dijelaskan

kepada anak-anak mereka. Saat anak-

anak keluarga Suku Sasak ditanyai

mengenai hal tersebut, mereka dapat

menjawab dan menjelaskannya dengan

baik. Mereka tidak mengeksploitasi

lahan produktif untuk pembangunan

fisik mengingat tanah yang subur mesti

diolah dan dijaga demi kesinambungan

sumber nafkah hidup mereka.

Selanjutnya, kotoran sapi yang dijadikan salah satu material lantai rumah dan Undak-undakan (tangga) berfungsi sebagai penghangat di malam hari dan pengusir lalat atau nyamuk. Penggunaan obat pembasmi nyamuk yang dibakar ataupun yang dengan menggunakan aerosol penghasil gas CFC dapat dikurangi. Atap rumah tradisional Sasak menggunakan daun ilalang, tiang dengan pohon bambu, dan dinding 262 dengan anyaman bambu. Hal tersebut merupakan tindakan yang memanfaatkan sumber daya alam secara alami tanpa menggunakan bahan-bahan alam yang didapat dari tindakan pengikisan bebatuan.

Pembangunan rumah dilakukan secara selektif dengan memilih tempat atau lahan yang sesuai. Mereka menghindari lahan bekas perapian, tempat sampah, dan bekas sumur. Hal tersebut jika diakitkan dengan ilmu ekologi bahwa tempat perapian memiliki kondisi humus yang baik sehingga dapat digunakan sebagai tempat menanam. Begitupula halnya dengan tempat pembuangan sampah, selain mengandung banyak humus, tempat pembuangan sampah memiliki populasi bakteri yang tinggi sehingga dapat menjadi sumber penyakit.

Pagar pembatas kampung ditanami pohon turi, kelor, jeruk limau, sirih, dan tanaman "apotek hidup" lain yang menjadi bahan obatobatan tradisional.Masyarakat Suku Sasak tidak akan membangun rumah berlawanan arah dan ukurannya berbeda dengan rumah yang lebih dulu 
Environmental Sensitivity dan Hubungannya... Nadirah\&Rizki Ananda

ada. Menurut mereka, melanggar konsep tersebut merupakan perbuatan melawan tabu (maliq lenget). Secara konsep ekologi, hal tersebut menguntungkan karena penggunaan lahan yang besar untuk membangun sebuah gedung dapat diminimalisir.

Setiap Jumat masyarakat Desa Sasak Ende melakukan “Jumat Bersih” untuk bersama-sama membersihkan daerah temat tinggal mereka. Anakanak kecil keluarga Suku Sasak diwajibkan untuk menggikuti kegiatan tersebut supaya terbiasa menjalankan kegiatan adat setempat. Selanjutnya pada malam harinya diselenggarkan kegiatan pengajian anak-anak sekaligus acara penyuluhan adat istiadat bagi anak dan masyarakat setempat.

\section{KESIMPULAN}

Berdasarkan hasil analisis data dan perhitungan statistik yang telah diuraikan maka dapat disimpulkan bahwa terdapat hubungan positif antara environmental sensitivity dengan perilaku pelestarian kearifan lokal pada anak usia dini di masyarakat Suku Sasak Desa Sasak Ende Sekong Lombok Nusa Tenggara Barat.

Kearifan lokal yang diterapkan di keluarga mengimplikasikan bahwa masyarakat Suku Sasak Desa Sasak Ende Lombok Tengah Nusa Tenggara Barat salah satunya menerapkan nilainilai pelestarian lingkungan. Budaya yang tertanam mengajarkan kepada anak-anak mereka secara turuntemurun untuk terus menjaga warisan budaya dengan tidak memanfaatkan alam dan lingkungan secara berlebihan sehingga hal tersebut dapat menjadi salah satu upaya dalam menjaga lingkungan.

Dari serangkaian budaya dan kearifan lokal pada masyarakat Suku Sasak yang diajarkan kepada anakanak mereka secara turun temurun dilakukan secara lisan,mencontohkan, dan terus menerus sehingga dapat membentuk perilaku pelestarian kearifan lokal pada anak usia dini di keluarga Suku Sasak.

\section{DAFTAR PUSTAKA}


JURNAL PENDIDIKAN USIA DINI

Volume 11 Edisi 2, November 2017

Andi, M. Suku Sasak Lombok. [online]. https://wisatanusatenggara.word press.com/wisata-nusa-tenggarabarat/dusun-sade/ [diakses pada 28 April 2017], 2010.

Aisyah, Siti. Perkembangan dan Konsep Dasar Pengembangan Anak Usia Dini. Universitas Terbuka: Jakarta, 2011.

Ayatrohaedi. Kepribadian Budaya Bangsa (Local Genius). Jakarta: Pustaka Pelajar, 1986.

Hungerford, H.,\& Volk. T. L. Changing learner behavior through environmental education The Journal of Environnrmfd Eductrtion Vol 1 No. 3, 1990.

Kementrian Kebudayaan dan Pariwisata RI. Kearifan Lokal Di Tengah Modernisasi. Jakarta: Pusat Penelitian dan Pengembangan Sumber Daya Kebudayaan dan Pariwisata Kementrian Kebudayaandan Parisiwata Republik Indonesia, 2011.

Metzger, Tina and Mcewen Douglas. Measurement of Environmental Sensitivity. Journal of Environmental Education. Volume 30 No. 4, 1999.

Palmer, .A. et al. An Overview of Significant Influences And Formative Experiences On TheDevelopment Of Adults' Environmental Awareness In Nine Countries, Environmental EducationResearch. Vol. 4 No. 4, 1998.

Pluess, Michael. Individual Differences in Environemntal
Sensitivity Child Development Perspectives Journal Vol 17 No. $1,2015$.

Putrawan I Made. Konsep-Konsep Dasar Ekologi Dalam Berbagai Aktivitas Lingkungan. Alfabeta: Bandung, 2014.

Santrock, J.W. Educational Psychology. University of Texas at Dallas Pulb: McGraw-Hill, 2009.

Sivek, D .J. \& Hungerfordh,. Predictors of responsible behavior in members of three Wisconsin conservation organizations, The Journal of Environmental Education, Vol. 21 No 2, 1990.

Sivek, D.J. Environmental Sensitivity among Wiconsin High Scool Student. Environmental Education ResearchVol. 8, No.2, 2012.

Setiowati, Titik. Menumbuhkan Kearifan Lokal pada Anak Usia Dini melalui Pendidikan Nilai. Jurnal Temu Ilmiah Nasional Guru (TING) IV, 2012.

Sunaryo, dan Yossa Istiadi. Pengembangan Istrumen Sensitivitas lingkungan dalam Rangka Peningkatan Wawasan Lingkungan Guru PAUD di Wilayah Jakarta. Jurnal Pendidikan Usia Dini Vol 11 Edisi 1, 2017.

Susilo, Rahmad Dwi K. Sosiologi Lingkungan. Jakarta: Rajawali Press, 2009.

Sufia R., Sumarmi, Amirudin. Kearifan Lokal Dalam Melestarikan Lingkungan Hidup (Studi Kasus Masyarakat Adat 
Environmental Sensitivity dan Hubungannya... Nadirah\&Rizki Ananda

Desa Kemiren Kecamatan

Glagah Kabupaten

Banyuwangi). Jurnal Pendidikan:

Teori, Penelitian, dan

Pengembangan Universitas
Negeri Malang. Volume 1 No. 4, 2016.

Undang-undang RI Nomor 20 tahun 2003 tentang Sistem Pendidikan Nasional pada Pasal 1 ayat 14. 